\title{
PENGARUH PENERAPAN MODEL PEMBELAJARAN CORE BERBANTUAN MASALAH TERBUKA TERHADAP KETERAMPILAN BERPIKIR KRITIS MATEMATIS SISWA
}

\author{
K.R Udyani, I.N Gita, I.P.P Suryawan \\ Jurusan Pendidikan Matematika, Universitas Pendidikan Ganesha \\ Singaraja, Indonesia \\ e-mail: ratnaudyani21a@gmail.com ,nyomangita@gmail.com ,putu.pasek@undiksha.ac.id
}

\begin{abstract}
Abstrak
Penelitian ini bertujuan untuk mengetahui apakah penerapan model pembelajaran CORE berbantuan masalah terbuka berpengaruh positif terhadap keterampilan berpikir kritis matematis siswa kelas VIII SMP Negeri 2 Singaraja. Penelitian ini menggunakan desain penelitian Post-test Only Control Group Design. Populasi penelitian ini adalah seluruh siswa Kelas VIII SMP Negeri 2 Singaraja tahun ajaran 2016/2017, yaitu sebanyak 546 orang. Pengambilan sampel pada penelitian ini menggunakan teknik cluster random sampling. Data keterampilan berpikir kritis matematis siswa dikumpulkan melalui tes keterampilan berpikir kritis yang berbentuk soal uraian dengan soal sebanyak lima butir. Data hasil tes keterampilan berpikir kritis matematis dianalisis menggunakan Uji-t satu ekor. Hasil pengujian hipotesis menunjukkan bahwa nilai $t_{\text {hitung }}=3,4999$ lebih dari $t_{\text {tabel }}=1,6675$, yang berarti $H_{0}$ ditolak Dengan demikian, keterampilan berpikir kritis matematis siswa yang dibelajarkan dengan model pembelajaran CORE berbantuan masalah terbuka lebih tinggi dari keterampilan berpikir kritis matematis siswa yang dibelajarkan dengan model pembelajaran konvensional. Ini berarti model pembelajaran CORE berbantuan masalah terbuka berpengaruh positif terhadap keterampilan berpikir kritis matematis.
\end{abstract}

Kata kunci: model pembelajaran CORE, masalah terbuka, berpikir kritis .

\begin{abstract}
The study aimed to find out the effect of CORE learning model supported by open-ended problem toward students' mathematics critical thinking skill of $8^{\text {th }}$ grade at SMP Negeri 2 Singaraja. This research employed post-test only control group design. The population of this research were 546 students from the $8^{\text {th }}$ grade of SMP Negeri 2 Singaraja in academic year 2016/2017. The sample was taken by using cluster random sampling technique. Meanwhile, the data of students' mathematics critical thinking skill were collected through critical thinking skill test that had 5 essay questions. Furthermore, the data would be analyzed by using one tail t-test. The result of the hypothesis testing shows that the value of $t_{\text {hitung }}=3,4999$ more than $t_{\text {tabel }}=1,6675$. It means that the $H_{0}$ is rejected. Based on the result, it can be concluded that CORE learning model supported by opened-ended problem is able to improve students' mathematics critical thinking skill rather than conventional learning model. In other words, CORE learning model supported by open-ended problem is able to give positive effect toward students' mathematic critical thinking skill.
\end{abstract}

Key words: CORE learning model, open-ended problem, mathematical critical thinking.

\section{PENDAHULUAN}

Perkembangan ilmu pengetahuan dan teknologi mengalami peningkatan yang sangat pesat dan telah membawa perubahan pada segala aspek kehidupan manusia di Indonesia. Dengan adanya kemajuan pada bidang IPTEK, secara tidak langsung akan terjadi kompetisi dalam segala hal terutama dalam sumber daya manusia (SDM). Penyiapan SDM yang berkualitas dapat dilakukan melalui pendidikan yang berkualitas. Melalui pendidikan yang berkualitas akan memperoleh SDM yang berpotensi dalam bidang ilmu pengetahuan dan teknologi. IImu pengetahuan dan teknologi tidak 
akan bisa berkembang tanpa adanya kontribusi dari matematika, karena matematika adalah ratu semua ilmu yang akan menjadi dasar perkembangan ilmu pengetahuan dan teknologi (Suherman, 2003).

Matematika merupakan ilmu pengetahuan yang sangat penting sebagai pembentuk sikap dan pola pikir. pendidikan matematika memegang peranan yang strategis dalam menyiapkan SDM yang berkualitas. Pentingnya pelajaran matematika ditandai dengan diberikannya mata pelajaran matematika yang terdapat pada setiap jenjang pendidikan. Pembelajaran matematika di sekolah khususnya merupakan proses pembelajaran yang didalamnya memuat unsur mendidik yang sangat kental. Tujuan pembelajaran matematika oleh Depdiknas, Kemendikbud (2013) secara khusus juga menyebutkan bahwa pembelajaran matematika pada kurikulum 2013 membiasakan siswa untuk dapat berpikir algoritmis dan dirancang supaya siswa harus berpikir kritis untuk menyelesaikan segala permasalahan yang diajukan.

Guru hendaknya melakukan pergeseran dari pengajaran yang menekankan pada keterampilan berpikir tingkat rendah ke pembelajaran yang menekankan pada keterampilan berpikir tigkat tinggi khususnya keterampilan berpikir kritis. Nilai rata-rata UN pada mata pelajaran matematika tahun 2016 mengalami penurunan dari tahun sebelumnya (Kemendikbud, 2016). Salah

satu penyebab dari penurunan tersebut adalah jumlah soal yang menggunakan keterampilan berpikir kritis mengalami peningkatan sebesar 10\% (Kemendikbud, 2016). Oleh karena itu, dalam pembelajaran matematika siswa tidak hanya dituntut pada nilai akhir yang diperolehnya, namun perlu dituntut untuk mampu menganalisis dengan mengembangkan pemikirannya khususnya menyangkut keterampilan berpikir kritis

Pembelajaran matematika di sekolah tidak semata-mata diarahkan pada penguasaan dan pemahaman konsep, namun perlu adanya peningkatan kemampuan dan keterampilan berpikir siswa, khususnya keterampilan berpikir tingkat tinggi yaitu salah satunya keterampilan berpikir kritis (critical thinking). Berkaitan dengan keterampilan berpikir kritis, Walker (dalam Redhana, 2012:352) menyatakan bahwa "keterampilan berpikir kritis merupakan suatu proses yang memungkinkan siswa memperoleh pengetahuan baru melalui proses pemecahan masalah dan kolaborasi". Keterampilan berpikir kritis penting dalam proses pembelajaran karena keterampilan ini memberikan kesempatan kepada siswa belajar melalui penemuan. Keterampilan berpikir kritis tidak dapat dikembangkan melalui metode ceramah. Keterampilan intelektual dari berpikir kritis yang meliputi berpikir analisis, berpikir sintesis, berpikir reflektif, dan sebagainya yang dapat dipelajari melalui aktualisasi penampilan. Keterampilan berpikir kritis adalah keterampilan yang dapat dipelajari.

Dengan kata lain, guru perlu mengajarkan siswa untuk belajar berpikir (teaching of thinking). Menurut Krulik \& Rudnick (dalam Humaira, 2015:28) mengemukakan bahwa "berpikir kritis meliputi kemampuan dan keterampilan menguji, menghubungkan, memfokuskan masalah pada bagian-bagian masalah, mengumpulkan dan mengorganisasi informasi, menentukan jawaban yang rasional, menentukan simpulan yang valid". Oleh karena itu, siswa perlu meningkatkan keterampilan berpikir kritis melalui latihan-latihan yang dilakukan sejak dini.

Berkaitan dengan keterampilan berpikir kritis, Walker (dalam Redhana, 2012:352) menyatakan bahwa "keterampilan berpikir kritis merupakan suatu proses yang memungkinkan siswa memperoleh pengetahuan baru melalui proses pemecahan masalah dan kolaborasi”. Keterampilan berpikir kritis tidak dapat dikembangkan melalui metode ceramah. Keterampilan intelektual dari berpikir kritis yang meliputi berpikir analisis, berpikir sintesis, berpikir reflektif, dan sebagainya yang dapat dipelajari melalui aktualisasi penampilan. Dengan 
kata lain, keterampilan berpikir kritis tidak akan berkembang dengan baik tanpa ada usaha sadar untuk mengembangkannya selama pembelajaran serta memerlukan latihan secara terus menerus agar dapat berkembang ke arah yang potensial. Siswa harus ditantang agar dapat mengembangkan keterampilan berpikir kritis selama pembelajaran.

Dalam hal ini guru harus mengupayakan pembelajaran matematika di sekolah dirancang untuk membiasakan siswa mengkonstruksi pengetahuannya sehingga dapat mendukung dan mengarahkan siswa untuk mengembangkan keterampilan berpikir kritis matematisnya. Upaya yang dapat dilakukan agar siswa dapat mengkonstruksi pengetahuanya dengan menggunakan metode diskusi. Dengan menggunakan metode diskusi diharapkan semua kemampuan siswa dapat digali dengan baik serta siswa dapat menjalin hubungan kerja sama antar siswa dengan baik.

Diskusi memberikan kesempatan kepada siswa untuk membahas suatu masalah, menciptakan suasana belajar yang menyenangkan dan meningkatkan kualitas interaksi antar siswa sehingga diharapkan akan berimbas pada peningkatan hasil belajar siswa. Siswa agar dapat berkontribusi dalam suatu diskusi haruslah mengingat informasi dan menggunakan pengetahuan yang dimilikinya untuk menghubungkan dan menyusun ide-idenya serta mengorganisasikan apa yang mereka ketahui. Kemudian dalam suatu diskusi juga siswa perlu memikirkan secara mendalam apa yang telah dipelajarinya yang nantinya akan membantu siswa untuk memperluas pengetahuannya. Dari uraian di atas, model pembelajaran yang menggunakan diskusi sebagai metodenya adalah model pembelajaran CORE.

Model pembelajaran CORE adalah model diskusi yang dapat mempengaruhi perkembangan pengetahuan dan menekankan kemampuan berpikir siswa untuk mengorganisasikan, menghubungkan, mengelola, dan mengembangkan informasi yang didapat. Calfee at al (dalam Mayasari, 2016:3) mengemukakan bahwa "model pembelajaran CORE mencakup empat proses/tahapan yang meliputi Connecting, Organizing, Reflecting, dan Extending". Dengan Connecting siswa diajak untuk menghubungkan pengetahuan baru yang akan dipelajari dengan pengetahuannya terdahulu. Organizing membawa siswa untuk dapat mengorganisasikan pengetahuannya. Kemudian Reflecting, siswa dilatih untuk dapat menjelaskan kembali informasi yang telah meraka dapatkan melalui diskusi yang baik tentunya dapat meningkatkan kemampuan berpikir reflektif yang melibatkan proses berpikir kritis. Tahap yang terakhir yaitu Extending diantaranya dengan kegiatan diskusi membantu memperluas pengetahuan siswa.

Hal di atas didukung dengan penelitian yang telah dilakukan Agung (2015) menyatakan bahwa model pembelajaran CORE mampu untuk meningkatkan kemampuan matematis siswa kelas X SMA Negeri 1 Babandem. Selain itu hasil penelitian oleh Beladina (2013) menyatakan bahwa kreativitas matematis siswa dengan menggunakan model pembelajaran CORE berbantuan LKPD lebih baik daripada kreativitas matematis siswa dengan menggunakan model pembelajaran konvensional. Dengan demikian, terlihat bahwa model pembelajaran CORE baik untuk diterapkan dalam proses pembelajaran matematika dalam rangka pengembangan keterampilan berpikir kritis.

Model pembelajaran CORE merupakan suatu pembelajaran yang menggunakan model diskusi. Model ini mengarahkan siswa berpikir secara kritis dalam persoalan yang diberikan oleh guru di kelas dan diharapkan siswa juga mampu mengkaitkan konsep matematika dengan konsep ilmu lain maupun kehidupan sehari-hari. Siswa dalam mengembangkan pemikirannya perlu dihadapkan pada permasalahan yang melatih daya nalar siswa. Permasalahan yang dapat menuntut cara siswa berpikir adalah masalah terbuka. 
Masalah terbuka adalah masalah yang memiliki kemungkinan adanya lebih dari satu jawaban yang benar atau lebih dari satu cara penyelesaian terhadap masalah tersebut. Melalui masalah terbuka secara sengaja tidak memberikan semua informasi secara lengkap berkaitan dengan masalah matematika yang harus dipecahkan oleh siswa atau menyembunyikan beberapa bagian informasi yang berkaitan dengan masalah. Masalah terbuka dalam hal ini akan disajikan dalam LKS guna memudahkan siswa dalam melatih pemikirannya. Dengan demikian, upaya siswa dalam melatih pemikirannya dapat dilaksanakan dengan model pembelajaran CORE yang berbantuan masalah terbuka.

Hal di atas, didukung Ridwan (2015) yang menyatakan bahwa dalam representasi beragam matematis siswa yang diberikan pembelajaran masalah terbuka lebih baik daripada siswa yang diberikan pembelajaran konvensional. Oleh karena itu, diharapkan model pembelajaran matematika yang berbasis masalah terbuka juga berpengaruh terhadap keterampilan berpikir kritis matematis siswa, Lestari (2013) dalam penelitiannya menyimpulkan bahwa antara siswa yang berjenis kelamin lakilaki dan perempuan pada umumnya mempunyai kemampuan yang sama. Hal ini terlihat pada tingkat kemampuan matematika tinggi baik siswa berjenis kelamin laki-laki dan perempuan dapat melalui keempat tahapan proses berpikir kritis dalam memecahkan masalah matematika open-ended (masalah terbuka). Sedangkan pada tingkat kemampuan sedang maupun rendah baik dari siswa berjenis kelamin laki-laki maupun perempuan tidak melalui satu atau lebih tahapan proses berpikir kritis dalam memecahkan masalah matematika open-ended. Dengan demikian, siswa dalam kegiatan diskusinya membutuhkan suatu masalah terbuka untuk mengkonstruksi pengetahuannya dan melatih kemampuan berpikirnya. Dengan demikian, upaya siswa dalam melatih pemikirannya dapat dilaksanakan dengan model pembelajaran CORE yang berbantuan masalah terbuka. $\begin{array}{ccc}\text { Model } & \text { pembelajaran } & \text { CORE } \\ \text { berbantuan } & \text { masalah } & \text { terbuka }\end{array}$ memungkinkan siswa untuk memperluas dan menerapkan pengetahuan serta keterampilan akademiknya dalam berbagai macam situasi di sekolah maupun di luar sekolah. Tujuannya adalah agar siswa mampu mengasah keterampilan berpikir kritisnya yang dihadapkan dengan suatu masalah terbuka. Salah satu tahap pada model pembelajaran CORE dalam hal ini adalah Reflecting. Pada tahap reflecting, siswa melalui proses berpikir kritis yang dapat diasah melalui latihan-latihan pada masalah terbuka. Dengan demikian, siswa akan terlatih dalam menganalisis masalah yang ditunjukkan dengan siswa telah merumuskan masalah, memberikan argumen, melakukan induksi dan evaluasi, dan mengambil keputusan dan tindakan.

Berdasarkan uraian di atas, penulis tertarik untuk mengkaji tentang pengaruh penerapan model pembelajaran CORE berbantuan masalah terbuka terhadap keterampilan berpikir kritis matematis. Oleh karena itu, penelitian ini akan mengkaji mengenai pengaruh model pembelajaran CORE berbantuan masalah terbuka terhadap keterampilan berpikir kritis matematis siswa.

\section{METODE}

Penelitian ini termasuk dalam kategori penelitian eksperimen semu dengan rancangan post-test only control group design. Populasi penelitian ini adalah seluruh siswa kelas VIII SMP Negeri 2 Singaraja yang terdistribusi dalam 15 kelas. kelima belas kelas tersebut persebarannya sama tanpa ada kelas unggulan. Oleh karena itu, seluruh kelas memiliki kesempatan yang sama untuk menjadi sampel dalam penelitian ini. Pengambilan sampel dalam penelitian ini ditentukan dengan teknik cluster random sampling. $\mathrm{Hal}$ ini dilakukan setelah memperhatikan ciri-ciri antara lain: (1) buku sumber yang digunakan sama; (2) siswa mendapatkan materi berdasarkan kurikulum yang sama; (3) siswa yang menjadi subjek penelitian duduk pada 
tingkat yang sama; (4) pembagian kelas tidak berdasarkan peringkat.

Penelitian ini menggunakan dua kelas sampel yang diambil dari 15 kelas yang ada, satu kelas sebagai kelompok eksperimen yaitu kelas yang diterapkan diterapkan model pembelajaran CORE berbantuan masalah terbuka dan satu kelas yang lain sebagai kelompok kontrol yaitu kelompok yang diterapkan model pembelajaran konvensional. Pada penelitian ini, kelompok eksperimen adalah kelas VIII.12 yang terdiri dari 36 siswa dan kelompok kontrol adalah kelas VIII.11 yang terdiri dari 36 siswa. Variabel bebas dalam penelitian ini adalah model pembelajaran CORE berbantuan masalah terbuka dan pembelajaran konvensional dan variabel terikatnya adalah keterampilan berpikir kritis matematis.

Teknik pengumpulan data yang digunakan adalah tes. Tes digunakan untuk memperoleh data tentang keterampilan berpikir kritis siswa. Soal tes dalam penelitian ini berbentuk uraian. Tes ini meliputi indikator keterampilan berpikir kritis yaitu (1) merumuskan masalah, (2) memberikan argumen, (3) melakukan induksi, (4) melakukan evaluasi, dan (5) mengambil keputusan dan tindakan.

Tes diberikan pada kedua kelompok sampel dengan instrumen tes yang sama. Dalam penelitian ini digunakan soal tes berbentuk uraian yang sebelumnya telah diujicobakan. Hasil tes tersebut digunakan sebagai data akhir yang dianalisis untuk menguji kebenaran hipotesis penelitian dalam membandingkan keterampilan berpikir kritis siswa dari kelompok eksperimen dan kelompok kontrol.

Teknik analisis data bertujuan untuk mengetahui ada tidaknya pengaruh penerapan model pembelajaran CORE berbantuan masalah terbuka terhadap keterampilan berpikir kritis matematis siswa. Sebelum dilakukan pengujian hipotesis, terlebih dahulu dilakuakn uji prasyarat. Untuk uji normalitas digunakan uji Liliefors sedangkan untuk uji homogenitasnya menggunakan uji $F$. Setelah melakukan uji prasyarat maka dilanjutkan dengan pengujian hipotesis mengunakan uji-t. Adapun rumus uji-t yang digunakan sebagai berikut.

$$
t_{h i t}=\frac{\bar{Y}_{1}-\bar{Y}_{2}}{\sqrt{\frac{s^{2}}{n_{1}}+\frac{s^{2}}{n_{2}}}}
$$

\section{HASIL DAN PEMBAHASAN}

Data yang diperoleh padapenelitian ini berupa data kuantitatif berupa skor post tes keterampilan berpikir kritis matematis siswa. Sebelum melakukan uji hipotesis perlu dilakukan beberapa uji prasyarat terhadap sebaran data yang meliputi uji normalitas terhadap data tes keterampilan berpikir kritis matematis. Uji normalitas ini menggunakan teknik Lilliefors. Keputusan uji sebaran data dilakukan dengan membandingkan nilai signifikansi ( $p$-value) yang diperoleh dengan nilai $\alpha=0,05$. Dalam hal ini, yang dikehendaki adalah nilai signifikansi lebih dari 0,05. Berdasarkan hasil uji normalitas pada tampak bahwa skor post test kedua kelompok diperoleh nilai signifikansi lebih dari 0,05 . Hal ini berarti sebaran data pada semua kelompok berdistribusi normal.

Setelah melakukan uji prasyarat yang pertama, yaitu uji normalitas, selanjutnya dilakukan uji prasyarat yang kedua, yaitu uji homogenitas. Uji homogenitas varians data keterampilan berpikir kritis matematis dianalisis melalui uji $\mathrm{F}$ dengan kriteria kedua kelompok memiliki varians homogen jika $F_{\text {hitung }}<$ $F_{\text {tabel }}$.

Berdasarkan Tabel 3, diperoleh bahwa kedua kelompok memiliki varians yang homogen. Selanjutnya akan dilakukan uji hipotesis menggunakan uji-t satu ekor (ekor kanan). Sebelumnya telah disampaikan bahwa data keterampilan berpikir kritis matematis siswa dari kelompok eksperimen dan kelompok kontrol berdistribusi normal dan homogen. Selain itu jumlah siswa pada tiap kelas sama, baik itu kelas eksperimen maupun kelas kontrol, sehingga uji-t yang 
digunakan adalah separated varians.

Adapun hasil analisis disajikan dalam

bentuk Tabel 1.

Tabel 1. Hasil Uji Hipotesis

\begin{tabular}{ccccccc}
\hline Kelompok & $\mathbf{N}$ & $\bar{X}$ & $\mathrm{SD}$ & $t_{\text {hitung }}$ & $t_{\text {tabel }}$ & \\
\cline { 1 - 5 } Eksperimen & 36 & 21,17 & 5,35 & 3,4999 & 1,6675 & CORE \\
Kontrol & 36 & 15,50 & 5,15 & 3,4999 & 1,6675 & bisa \\
memilik \\
i
\end{tabular}

Berdasarkan hasil perhitungan uji$t$, diperoleh bahwa $t_{\text {hitung }}>t_{\text {tabel }}$ sehingga $H_{0}$ ditolak. Dengan demikian dapat diinterpretasikan bahwa terdapat perbedaan yang signifikan keterampilan berpikir kritis matematis antara siswa yang mengikuti pembelajaran dengan model pembelajaran CORE berbantuan masalah terbuka dan siswa yang mengikuti pembelajaran dengan model pembelajaran konvensional.

Berdasarkan deskripsi data hasil penelitian, keterampilan berpikir kritis matematis siswa yang mendapat pembelajaran dengan model pembelajaran CORE berbantuan masalah terbuka lebih tinggi daripada keterampilan berpikir kritis matematis siswa yang mendapat pembelajaran dengan model pembelajaran konvensional. Hal tersebut bisa terjadi karena keunggulan yang dimiliki oleh model pembelajaran CORE berbantuan masalah terbuka dibandingkan dengan model pembelajaran konvensional.

$\begin{array}{ccc}\text { Model } & \begin{array}{c}\text { pembelajaran } \\ \text { memiliki }\end{array} & \text { CORE } \\ \text { langkah-langkah yang }\end{array}$ pembelajaran yang dapat mempengaruhi siswa untuk mengembangkan pengetahuannya dalam melatih proses berpikir siswa sehingga pola pikir siswa lebih sistematis dan kritis. Kemampuan pemahaman matematika siswa sangat erat kaitannya dengan keterampilan berpikir kritis matematis siswa. Seseorang yang mampu menampilkan kemampuan pemahaman konsep matematika mensyaratkan bahwa seseorang tersebut telah melakukan proses berpikir secara kritis yang dilatih terus-menerus. Jadi siswa yang dibelajarkan dengan model keterampilan berpikir kritis yang lebih tinggi.

Masalah matematika terbuka memberikan kesempatan kepada siswa untuk menggunakan pemikiranya tehadap permasalahan yang memiliki banyak kemungkinan solusi/jawaban. Penyajian masalah matematika terbuka dalam bentuk Lembar Kerja Siswa (LKS) yang digunakan sebagai sarana siswa dalam melatih proses berpikir kritisnya. Pada LKS ini terdapat beberapa bagian yang pertama adalah "Analisis Masalah" yang melatih siswa untuk dapat mengidentifikasi permasalahan serta memberikan pendapat mengenai permasalahan matematika terbuka pada LKS. Kedua terdapat bagian "Pemecahan Masalah" pada bagian ini siswa dapat menuliskan hasil identifikasi pada bagian analisis masalah dengan memberikan solusi yang tidak tunggal sehingga siswa dituntut untuk memberikan alternatif solusi serta pemberian alasan siswa memperoleh suatu cara penyelesaian. Dan yang ketiga pada bagian "Kesimpulan" siswa memberikan kesiimpulan yang telah diperoleh terhadap permasalahan pada LKS yang kemudian kesimpulan tersebut kemudian digeneralisasikan.

Melalui tambahan alternatif solusi/jawaban yang berbeda maka otak siswa akan dipenuhi oleh kemungkinankemungkinan jawaban yang ada, sehingga berbagai pertanyaan akan muncul dibenaknya dan tidak mungkin pertanyaan itu akan langsung ditanyakan pada guru. Tentunya guru dalam menanggapi pertanyaan siswa tidak boleh langsung memutuskan apakah jawaban siswa tersebut benar atau salah, namun mungkin bisa melakukan umpan balik kepada siswa. 
Dalam proses berpikir kritis melalui bantuan masalah matematika terbuka siswa tidak hanya dimint untuk menentukan suatu jawaban benar atas permasalahan yang diberikan melainkan juga diminta untuk menjelaskan pola pikir mereka melalui proses penalaran di mana hal ini dapat menjadi salah satu sumber informasi guru dalam melihat keberhasilan pembelajaran yang dilaksanakan. Dengan penalaran yang baik dalam memahami masalah yang dilakukan secara kontinu akan membuat siswa lebih mudah untuk menentukan kemungkinan-kemungkinan solusi terhadap masalah yang dihadapinya yang akhirnya bermuara pada peningkatan keterampilan berpikir kritis matematis siswa.

Proses berpikir kritis dalam penerapan model pembelajaran CORE dengan berbantuan masalah terbuka dilakukan dalam diskusi kelompok. Diskusi kelompok dalam pembelajaran di kelas dapat melatih siswa untuk melakukan tukar pendapat sehingga setiap siswa mempunyai kesempatan untuk menyampaikan atau mengkomunikasikan ide-idenya serta memberikan pertimbangan kepada siswa yang lain dalam memutuskan kemungkinan solusi masalah. Selain itu, siswa juga dapat dengan mudah mencari bantuan dari temannya sehingga siswa tidak mudah menyerah dan lebih termotivasi dalam menyelesaikan permasalahan. Masalah matematika terbuka yang disajikan dalam bentuk LKS memberikan kesempatan kepada siswa untuk melatih proses berpikir kritisnya untuk menginvestigasi berbagai kemungkinan solusi yang diyakininya dalam menentukan solusi dari permasalahan yang diberikan.

$\begin{array}{cc}\text { Tahap } & \text { selanjutnya } \\ \text { perwakilan dari beberapa } & \text { kelompok }\end{array}$ diberikan kesempatan untuk mempresentasikan hasil diskusinya di depan kelas. Tahap ini merupakan wahana siswa untuk melakukan pertukaran ide antar kelompok. Solusi atau alternatif solusi lain pemecahan masalah dari siswa perlu diperhatikan agar terjadi pertukaran ide dalam proses pembelajaran. Adanya pertukaran informasi dan ide membawa dampak positif terhadap semua anggota kelompok baik yang berkemampuan kurang maupun yang berkemampuan lebih baik. Mereka juga dilatih untuk menghargai pendapat teman dengan adanya penyelesaian masalah yang bervariasi dari masingmasing kelompok. Setelah mempresentasikan hasil diskusinya, siswa melakukan refleksi. Siswa memantau prosedur penyelesaian masalah yang diperoleh dari proses berpikir kritis hingga mencapai suatu jawaban, menanyakan hal-hal yang belum dipahami, dan melakukan generalisasi dari permasalahan yang diberikan sehingga siswa mampu mengaitkan atau mengembangkan konsep dan keterampilan yang diperolehnya untuk situasi yang berbeda.

Dalam hal ini, guru berkewajiban untuk mengingatkan dan membimbing siswa tersebut. Siswa diminta untuk menyelesaiakan permasalahan yang ada di LKS melalui diskusi kelompok. Kelompok yang dapat menjawab dengan benar dan mempresentasikan hasilnya di depan kelas akan mendapatkan reward.

Pemberian reward dilakukan untuk memicu siswa agar lebih bersemangat dan bekerja keras dalam menyelesaiakan soal-soal. Ketika salah satu kelompok mempresentasikan hasil diskusinya maka kelompok lain diminta untuk memperhatikan dan mengoreksi jawaban kelompoknya sendiri apakah masih terdapat kesalahan atau tidak. Peneliti juga mengelola proses

pembelajaran dengan menerapkan langkah-langkah

sesuai dengan RPP yang telah disusun.

Pada pertemuan pertama, kondisi kelas kurang kondusif, siswa masih sibuk dengan kegiatannya masing-masing seperti mengobrol dengan temannya atau melakukan kegiatan lain yang tidak berhubungan dengan pelajaran sehingga mengganggu konsentrasinya dalam belajar.

Selama proses pembelajaran siswalah yang aktif melakukan seluruh rangkaian pembelajaran seperti menemukan solusi dari suatu masalah, melakukan diskusi dengan anggota kelompok, dan mempresentasikan hasil 
diskusinya di depan kelas yang disertai pemberian alasan atas konsep yang digunakan dalam menyelesaikan permasalahan. Peran guru dalam hal ini yaitu sebagai fasilitator dan motivator, menyediakan kondisi yang kondusif bagi berlangsungnya proses pembelajaran. Guru tidak langsung menerangkan materi namun memberikan kesempatan kepada siswa untuk menemukan sendiri konsep atau mengkonstruksi sendiri pengetahuannya. Semua kegiatan yang dilakukan membawa dampak positif terhadap keterampilan berpiki kritis matematis siswa.

Sejalan dengan penelitian Beladina (2013) pembelajaran dengan model pembelajaran CORE mampu menghasillkan kreativitas matematis siswa lebih baik daripada pembelajaran konvensional. Melalui penelitian ini, Beladina menemukan berbagai dampak positif penerapan model pembelajaran CORE dalam pembelajaran matematika antara lain (1) mampu menghasilkan kreativitas matematis siswa lebih baik dari pembelajaran konvensional, memberikan kesempatan pada siswa untuk dapat terlibat aktif dalam pembelajaran. Dalam penelitian yang dilakukan oleh Beladina, ada beberapa kelemahan yang didapatkan yaitu saat berlangsungnya pembelajaran, seringkali siswa menemui kesulitan dalam menggunakan pemikirannya untuk menyelesaikan suatu permasalahan. Dengan adanya bantuan masalah matematika terbuka, siswa lebih terdorong untuk mengembangkan proses berpikir kritisnya dalam menyelesaikan permasalahan. Dari pertama siswa dihadapkan dengan suatu permasalahan terbuka pada LKS, kemudian siswa melakukan analisis-analisis. Berdasarkan analisis tersebut siswa mampu menggunakan hasil pemikirannya dalam penyelesaian masalah.

Berdasarkan pembelajaran yang telah dilakukan, penerapan model pembelajaran CORE berbantuan masalah terbuka dapat membuat (1) siswa berpartisipasi aktif dalam pembelajaran dan aktif mengekspresikan ide-idenya, (2) siswa memiliki kesempatan lebih banyak dalam memanfaatkan pengetahuan dan keterampilan matematika yang telah dimiliki, (3) siswa termotivasi untuk memberikan bukti atau penjelasan dari kemungkinan solusi yang dipilih dalam menyelesaikan permasalahan, (4) siswa dapat merespon permasalahan dengan cara mereka sendiri, dan (5) pengalaman siswa lebih banyak dalam menjawab permasalahan sehingga dapat meningkatkan pengetahuannya. Hasil tersebut mendukung terjadinya peningkatan keterampilan berpikir kritis matematis siswa.

Model pembelajaran CORE yang

diterapkan pada kelas eksperimen didukung dengan penggunaan LKS yang memuat masalah terbuka sebagai media siswa untuk belajar mengkonstruksi pengetahuannya sendiri yang dikembangkan dari informasi informasi yang telah dipelajari sebelumnya. Oleh karena itu, pada penelitian ini diterapkan model pembelajaran CORE berbantuan masalah terbuka. Dalam pelaksanaan kegiatan pembelajaran, guru berpedoman pada RPP yang telah disusun. Namun pada kenyataannya, peneliti sebagai guru masih menemui beberapa kendala. Pada pertemuan pertama, kegiatan diskusi kelompok kurang bisa berjalan dengan lancar. Siswa belum dapat sepenuhnya berkonsentrasi pada kelompoknya masing-masing. Beberapa siswa masih suka berjalan-jalan ke kelompok lain sehingga siswa tidak dapat fokus dalam menyelesaiakan permasalahan dikelompoknya dan mengganggu kelompok lain.

Dari uraian di atas memberikan gambaran bahwa model pembelajaran CORE berbantuan masalah terbuka dalam pembelajaran matematika membawa dampak positif terhadap keterampilan berpikir kritis matematis siswa. Oleh karena itu, model pembelajaran CORE berbantuan masalah terbuka dapat dijadikan sebagai salah satu alternatif pembelajaran yang kreatif dan inovatif dalam upaya peningkatan mutu pendidikan khususnya dalam pembelajaran matematika. 


\section{SIMPULAN DAN SARAN}

Berdasarkan rumusan masalah, tujuan, hasil analisis, dan pembahasan yang telah diuraikan sebelumnya, dapat disimpulkan bahwa keterampilan berpikir kritis matematis siswa yang dibelajarkan dengan model pembelajaran CORE berbantuan masalah terbuka lebih tinggi daripada keterampilan berpikir kritis matematis siswa yang dibelajarkan dengan model pembelajaran konvensional. Oleh karena itu, model pembelajaran CORE berbantuan masalah terbuka berpengaruh positif terhadap keterampilan berpikir kritis matematis siswa. Berdasarkan hasil penelitian yang diperoleh, peneliti melalui tulisan ini mengajukan beberapa saran. Adapun saran-saran yang dapat disampaikan antara lain, (1) Praktisi pendidikan, khususnya yang terlibat dalam pembelajaran matematika layak untuk menggunakan model pembelajaran CORE berbantuan masalah terbuka sebagai salah satu alternatif model pembelajaran yang dapat diterapkan di kelas; (2) Para peneliti yang lain yang teratrik disarankan untuk melakukan penelitian terhadap model pembelajaran CORE berbantuan masalah terbuka pada sampel yang elbih besar dan apada materi yang lain untuk mengetahui pengaruh penerapan model pembelajaran CORE dalam pembelajaran matematika secara lebih mendalam

\section{DAFTAR PUSTAKA}

Agung, P. 2015. Pengaruh Model Pembelajaran CORE terhadap Kemampuan Komunikasi Matematis Siswa Kelas X SMA Negeri 1 Bebandem. Skripsi (tidak diterbitkan). Universitas Pendidikan Singaraja Beladina. 2013. Keefektifan Model Pembelajaran CORE Berbantuan LKPD terhadap Kreativitas Matematis Siswa. Tersedia pada http://journal.unnes.ac.id/sju/index.p hp/ujme. (diakses pada tanggal 13 Oktober 2016)

Humaira. 2015. Penerapan Metode Dialog Socratic untuk Meningkatkan Hasil Belajar dan Keterampilan Berpikir Kritis Siswa Kelas VIII E SMP Negeri 1 Sukasada Tahun Pelajaran 2011/2012 pada Mata Pelajaran IPA (Fisika).Skripsi (tidak diterbitkan) Universitas Pendidikan Ganesha.

Kemendikbud (Kementrian Pendidikan dan Kebudayaan). 2016. Paparan Hasil Ujian Nasional 2016. Tersedia pada

http://www.kemendikbud.go.id/

(diakses tanggal 4 maret 2017)

Mayasari. 2016. Efektivitas Model Pembelajaran Kooperatif Tipe CORE pada Materi Pokok Fungsi di SMA Negeri 1 Campurdarat. Tersedia pada https://simki.unpkediri.ac.id/mahasis wa/file_artikel/2016/11.1.01.05.0124 .pdf. (diakses tanggal 13 Oktober 2016)

Redhana. 2012. Model Pembelajaran Berbasis Masalah dan Pertanyaan Socratik untuk Meningkatkan Keterampilan Berpikir Kritis Siswa. Jurnal Pendidikan. 351-365.

Ridwan, Y. 2014. Meningkatkan Kemampuan Representasi Beragam Matematis Siswa Melalui Pembelajaran Berbasis Masalah Terbuka. Tersedia pada http://journal.unsika.ac.id/index.php /solusi/article/viewFile/71/71 (diakses pada tanggal 29 Januari 2017)

Suherman, Erman dkk. 2003. Strategi Belajar Mengajar Matematika Kontemporer. Jakarta: Dirjen Pendidikan Dasar dan Menengah. 